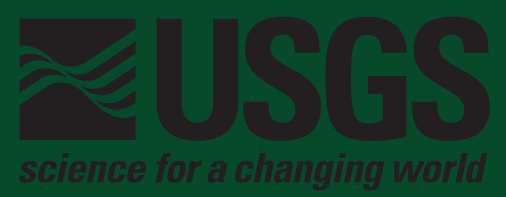

\title{
Velocity and Density Models Incorporating the Cascadia Subduction Zone for 3D Earthquake Ground Motion Simulations
}

Open-File Report 2007-1348

\author{
U.S. Department of the Interior
}

U.S. Geological Survey 


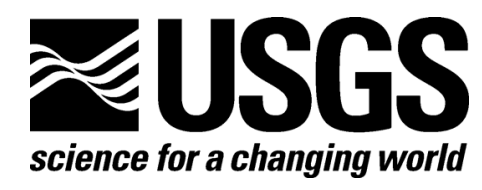

Earthquake Hazards Ground Motion Investigations

\title{
Velocity and Density Models Incorporating the Cascadia Subduction Zone for 3D Earthquake Ground Motion Simulations
}

\author{
Version 1.3 \\ By W.J. Stephenson
}

Open-File Report 2007-1348

U.S. Department of the Interior U.S. Geological Survey 


\title{
U.S. Department of the Interior DIRK KEMPTHORNE, Secretary
}

\author{
U.S. Geological Survey \\ Mark D. Myers, Director
}

U.S. Geological Survey, Reston, Virginia 2007

For product and ordering information:

World Wide Web: http://www.usgs.gov/pubprod

Telephone: 1-888-ASK-USGS

For more information on the USGS - the Federal source for science about the Earth, its natural and living resources, natural hazards, and the environment:

World Wide Web: http://www.usgs.gov

Telephone: 1-888-ASK-USGS

Any use of trade, product, or firm names is for descriptive purposes only and does not imply endorsement by the U.S. Government.

Although this report is in the public domain, permission must be secured from the individual copyright owners to reproduce any copyrighted material contained within this report.

\section{Suggested citation:}

Stephenson, W.J., 2007, Velocity and density models incorporating the Cascadia subduction zone for $3 \mathrm{D}$ earthquake ground motion simulations, Version 1.3: U.S. Geological Survey, Earthquake Hazards Ground Motion Investigations, Open-File Report 2007-1348, 24 p. 


\section{Contents}

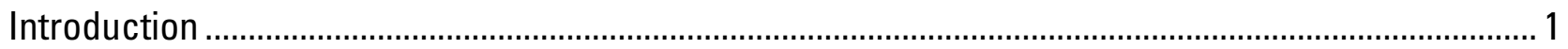

The Primary Geology-Based Model Units and Their Velocity-Density Properties.................................. 5

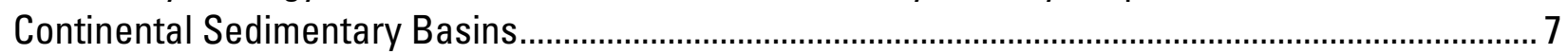

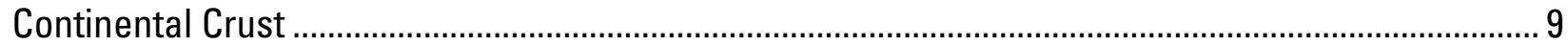

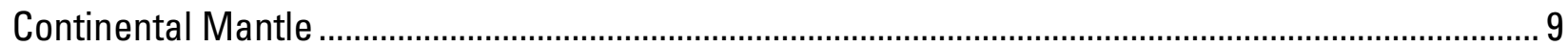

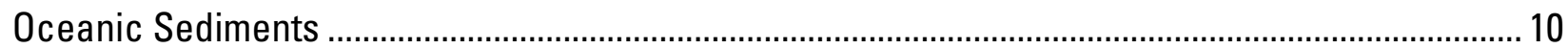

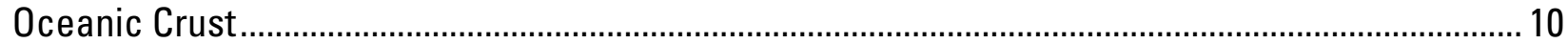

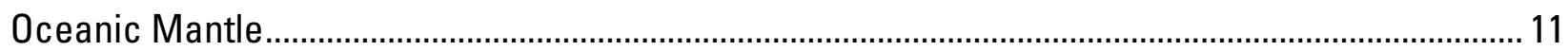

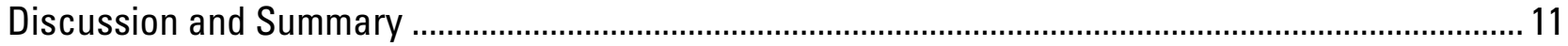

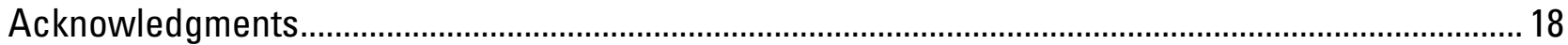

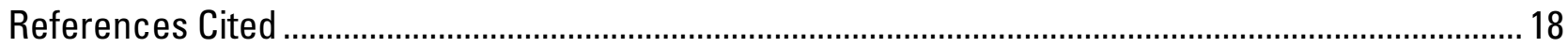

\section{Figures}

1. Region of velocity and density models described in this report....................................................

2. Contour map of Cascadia subduction slab.................................................................................... 4

3. Model volume sliced both east-west and north-south through urbanized sedimentary

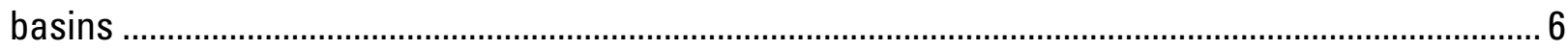

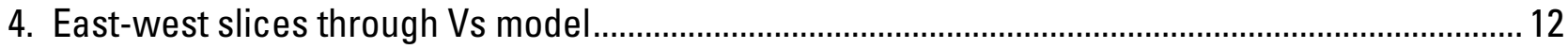

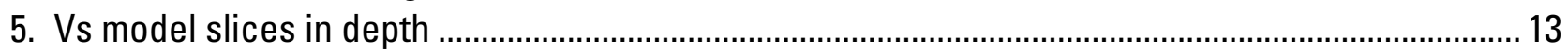

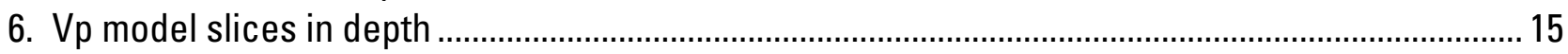

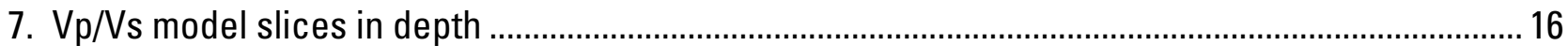

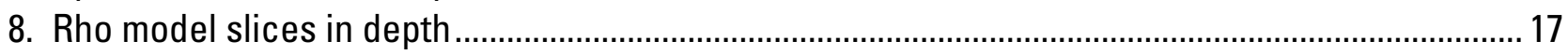




\section{Velocity and Density Models Incorporating the Cascadia Subduction Zone for 3D Earthquake Ground Motion Simulations}

By W.J. Stephenson

\section{Introduction}

In support of earthquake hazards and ground motion studies in the Pacific Northwest, three-dimensional P- and S-wave velocity (3D Vp and Vs) and density (3D rho) models incorporating the Cascadia subduction zone have been developed for the region encompassed from about $40.2^{\circ} \mathrm{N}$ to $50^{\circ} \mathrm{N}$ latitude, and from about $-122^{\circ} \mathrm{W}$ to $-129^{\circ} \mathrm{W}$ longitude (fig. 1). The model volume includes elevations from $0 \mathrm{~km}$ to $60 \mathrm{~km}$ (elevation is opposite of depth in model coordinates). Stephenson and Frankel (2003) presented preliminary ground motion simulations valid up to $0.1 \mathrm{~Hz}$ using an earlier version of these models. The version of the model volume described here includes more structural and geophysical detail, particularly in the Puget Lowland as required for scenario earthquake simulations in the development of the Seattle Urban Hazards Maps (Frankel and others, 2007). Olsen and others (in press) used the model volume discussed here to perform a Cascadia simulation up to $0.5 \mathrm{~Hz}$ using a Sumatra-Andaman Islands rupture history. As research from the EarthScope Program (http://www.earthscope.org) is published, a wealth of important detail can be added to these model volumes, particularly to depths of the upper-mantle. However, at the time of development for this model version, no EarthScope-specific results were incorporated. This report is intended to be a reference for colleagues and associates who have used or are planning to use this preliminary model in their research. To this end, it is intended that these models will be 
considered a beginning template for a community velocity model of the Cascadia region as more data and results become available.

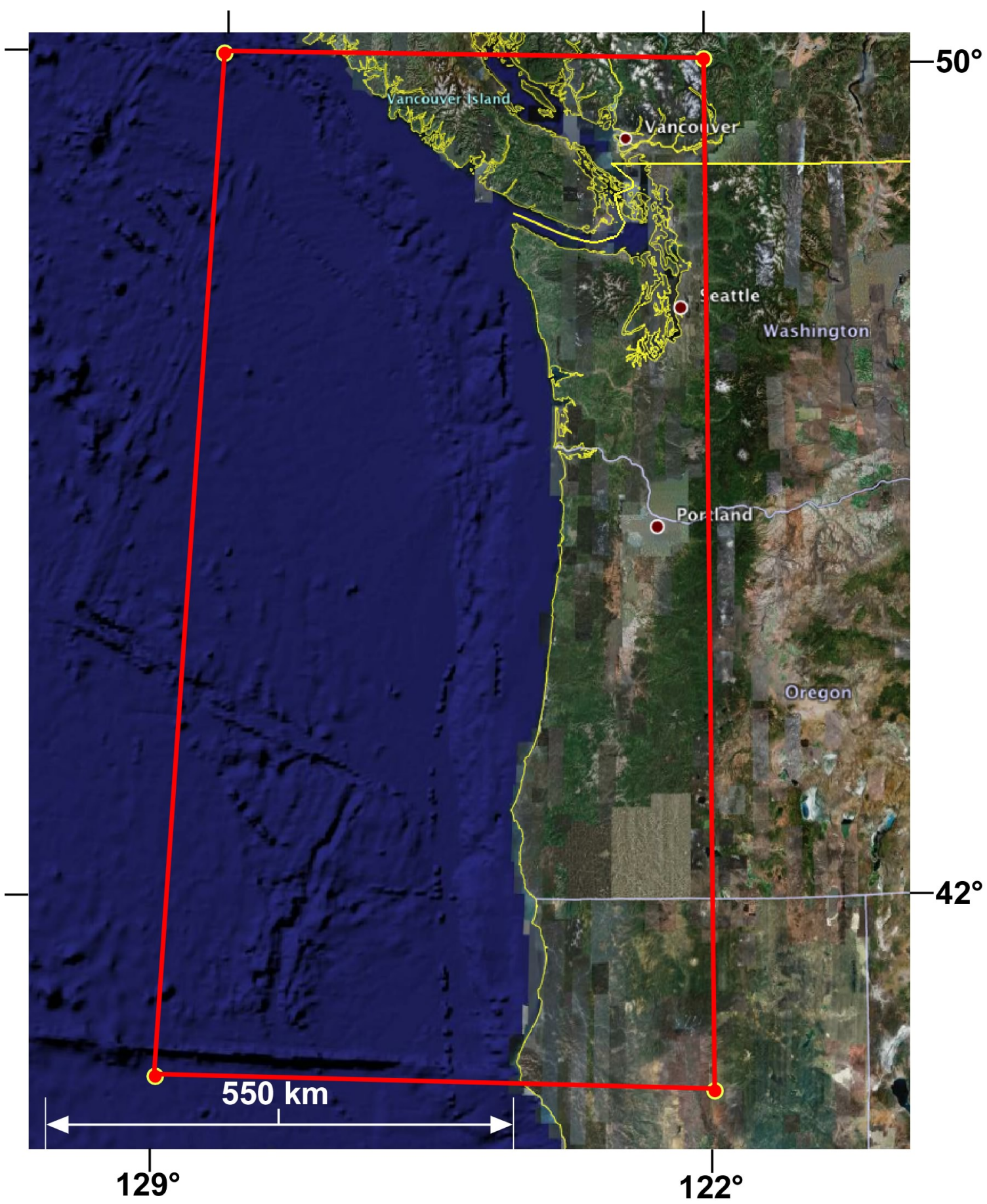


Figure 1. Region of velocity and density models described in this report. Base image is from GoogleEarth ${ }^{\circledR}$, showing the urban centers of Portland, Oreg., Seattle, Wash., and Vancouver, British Columbia. Red polygon is approximate boundary of velocity and density property volumes that include the Cascadia subduction zone. Latitude and longitude coordinates at corners of red polygon are, clockwise from upper left, $50^{\circ} \mathrm{N}$, $-129^{\circ} \mathrm{W} ; 50^{\circ} \mathrm{N},-122^{\circ} \mathrm{W} ; 40.2^{\circ} \mathrm{N},-122^{\circ} \mathrm{W}$; and $40.2^{\circ} \mathrm{N},-129^{\circ} \mathrm{W}$. Projection is geographic WGS 84.

The Cascadia subduction zone stretches for over $1,000 \mathrm{~km}$, from the Mendocino triple junction off the northern California coast northward to Vancouver Island, Canada (fig. 2). The primary reasons for developing these model volumes are (1) for simulating strong ground motions in the urbanized sedimentary basins of western Washington and Oregon and (2) for simulating Tsunami effects from a great (M 8-9) Cascadia subduction zone earthquake. As such, these are geophysical property models constrained by firstorder geologic boundaries only. No effort has been made to represent detailed geologic terranes in the model volume unless they were deemed important for ground motion variability in urbanized regions. Thus, unique terranes within the continental crust, such as Siletz or Wrangellia, are not treated as unique units within the model; however, these units are essentially represented de facto through the use of passive- and active-source tomographic imaging results.

The velocity and density models were developed primarily with EarthVision ${ }^{\circledR}$ software on the Solaris operating system. Matlab ${ }^{\circledR}$ was also used as part of the development of the density model and for performing quality-control of the model volumes output in Institute of Electrical and Electronics Engineers, Incorporated (IEEE) 
binary format from EarthVision ${ }^{\circledast}$. While a wealth of published information for the Cascadia region has been incorporated in the development of these models, significant smoothing during extrapolation and interpolation in portions of the model were required to create the model interfaces and geophysical property volumes. Because there are many areas within the model where published data are sparse or of low resolution, there is significant uncertainty and therefore subjectivity involved in building model horizons and in populating the model volumes.

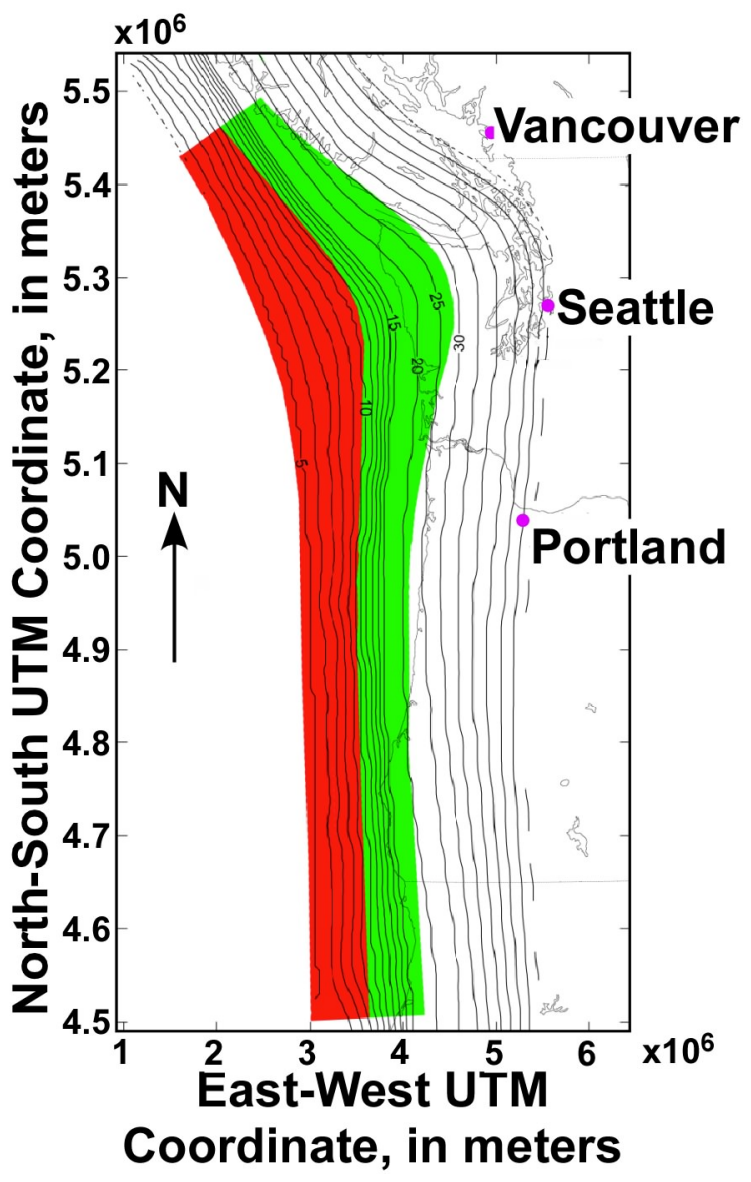

Figure 2. Contour map of Cascadia subduction slab showing estimated locked (red) and transitional (green) zones (Flück and others, 1997; McCrory and others, 2005). Contours in kilometers below sea-level. Figure is modified from Olsen and others (in press). 
The model volume incorporates bathymetry (data of etopo5; Wessel and Smith, 1991) but does not incorporate topography. Topography was not included in the current version of the model volume because the initial objective in developing these models was for use in 3D finite-difference ground motion calculations with modeling codes that do not allow grid points for terrain. This omission of topography in the current model volume can be easily rectified in future versions using EarthVision ${ }^{\circledR}$.

\section{The Primary Geology-Based Model Units and Their Velocity- Density Properties}

The backbone of the property volumes is the geologic model consisting of autonomous units representing simplified geologic volumes. For the purposes of this model, six units were defined. As shown in figure 3, these are (1) continental sedimentary basins, (2) continental crust, (3) continental mantle, (4) oceanic sediments, (5) oceanic crust, and (6) oceanic mantle. In addition to the Cascadia megathrust, the Seattle fault was incorporated into these models because of its use as a seismogenic source in the Seattle Urban Hazards Maps (Frankel and others, 2006). The modeling demands for the smaller-scale Seattle maps also drove the more detailed, complex overall appearance of the Puget Lowland region in the current velocity and density models. The Seattle fault delimits the southern edge of the Seattle basin and thrusts crystalline crust over basin sediments, creating a sharp lateral velocity-density contrast. Its surface trace was extracted from Blakely and others (2002) and projected to a depth of about $20 \mathrm{~km}$ assuming a $45^{\circ}$ south dip. This dip angle is essentially a median value based on the range of dips published from seismic reflection surveys (Pratt and others, 1997; Johnson and others, 1999; ten Brink and others, 2002; Calvert and others, 2003). Additional crustal faults may be incorporated into the model as need and additional information arise. 
Because much of the velocity information published in the literature is P-wave velocity $(\mathrm{Vp})$, this property was first derived for each unit in the geologic model, then relationships between $\mathrm{Vp}$ and both S-wave velocity (Vs) and density (rho) were used to derive these latter properties on a geologic unit-by-unit basis. First, Vp was defined for each unit based on available published results. Then Vp was converted to Vs using the empirical relation with depth of Brocher (2005), except for Quaternary and Tertiary sedimentary basin units. Property Vs for these units is defined in a later section, entitled “Continental Sedimentary Basins.”

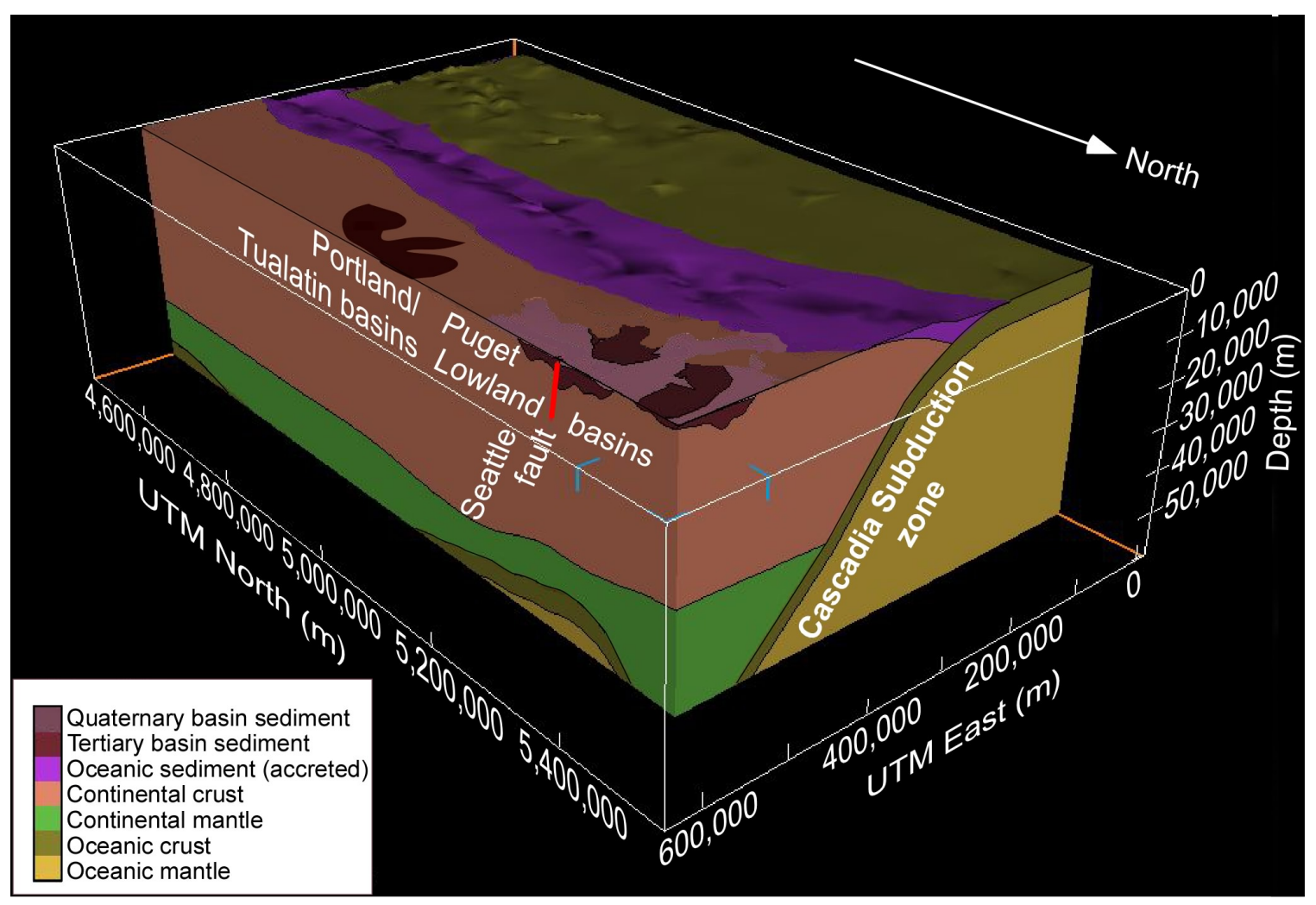

Figure 3. Model volume sliced through urbanized sedimentary basins overlying Cascadia subduction zone (for example, the Seattle and Tacoma basins) of the Puget Lowland, western Washington. Cascadia velocity and density models cover $40.2^{\circ}$ to $50^{\circ}$ $\mathrm{N}$. latitude, $-121^{\circ}$ to $-129^{\circ} \mathrm{W}$. longitude, and $0-$ to $-60-\mathrm{km}$ elevation. Bathymetry is 
included while topography above mean sea level $(0 \mathrm{~m})$ is excluded. Model projected into Universal Transverse Mercator Zone 10 North (UTM) coordinates for display. Sliced view shows the seven basic geology-based model units and their relationships at depth. Cascadia subduction fault surface is inferred along top of oceanic crust model unit. Seattle fault is shown by red line within the Puget Lowland basins; fault dip within model volume is $45^{\circ}$ south.

As noted earlier, rho values for all model units were calculated directly from the empirical relationship with Vp derived by Brocher (2005), which is approximately the deterministic form of the Nafe-Drake law. This empirical equation is:

$$
\text { rho }=1.6612^{*} V p-0.4721^{*} V p^{2}+0.0671^{*} V p^{3}-0.0043^{*} V p^{4}+0.000106^{*} V p^{5}
$$

where $\mathrm{Vp}$ is in $\mathrm{km} / \mathrm{s}$ and rho is in $\mathrm{g} / \mathrm{cm}^{3}$. After this calculation, the minimum and maximum nonwater densities were then constrained to be $2.0 \mathrm{~g} / \mathrm{cm}^{3}$ and $3.5 \mathrm{~g} / \mathrm{cm}^{3}$, respectively. Ocean water was set to $1.028 \mathrm{~g} / \mathrm{cm}^{3}$.

\section{Continental Sedimentary Basins}

Sedimentary basin deposits are further subdivided into Quaternary and Tertiary geologic units. The thickness of Quaternary deposits through the southern Puget Lowland was compiled by Jones (1996) and Johnson and others (1999), and was originally used by Frankel and Stephenson (2000) then later by Pitarka and others (2004) for 3D ground motion modeling of the Seattle basin. For the Quaternary thickness through eastern Juan de Fuca Strait, the data of Mosher and Johnson (2000) were incorporated to create the Quaternary-Tertiary interface throughout the Puget Lowland. 
Quaternary Vp varied one-dimensionally with a range of 1,500, 1,905, and 1,980 m/s at 0,200 , and 1,000 $\mathrm{m}$ depth, respectively. These values were derived from land surface measurements and high-resolution marine seismic surveys (for example, Williams and others, 1999; Calvert and others, 2003). The Quaternary unit Vs is derived from Vs30 and $\mathrm{Vp} 30$ measurements at the surface to constrain $\mathrm{Vp} / \mathrm{Vs}$ to approximately 2.5, while $\mathrm{Vp} / \mathrm{Vs}$ at $1 \mathrm{~km}$ was constrained to approximately 2.2. The minimum $\mathrm{Vs}$ in the Quaternary unit, and also in all nonwater regions of the model volume, was constrained to $600 \mathrm{~m} / \mathrm{s}$. For water regions, Vs was set to 0 .

The base of the Tertiary sediments within the Puget Lowland is inferred to be at the 4,500-m/s velocity contour, based on oil-industry borehole data (Brocher and Ruebel, 1998). This contour surface was extracted from the Seismic Hazards Investigations in the Puget Sound (SHIPS) and earthquake data 3D P-wave tomography of Ramachandran and others $(2004,2006)$, which incorporate the same or similar data from many previous tomography studies in the lowland (for example, Stanley and others, 1999; Brocher and others, 2001; Van Wagoner and others, 2002). The Willammette Valley basin deposits (Portland area) are derived from well data intersecting crystalline rocks under (generally) Tertiary deposits (Yeats and others, 1996; Gannett and others, 1998). Quaternary deposits are generally less than $30 \mathrm{~m}$ in thickness and are currently not included in the model region for these basin deposits. Future consideration of simulations requiring grid spacing less than $100 \mathrm{~m}$ should include a thin Quaternary layer. Additionally, recent gravity modeling has suggested that a significant thickness of lower-density sediment may exist in the Tualatin basin west of Portland below what is interpreted in this model as the base of basin sediments (about 12-km depth versus about $0.5-\mathrm{km}$ depth in current model; McPhee and others, 2007). 
The Vp of the Tertiary subunit in the Puget Lowland basins is defined by tomography results from SHIPS and local earthquake data as calculated by Ramachandran and others $(2004,2006)$. The Vp within the Willammette Valley basin deposits assumes a similar velocity-depth structure to that of the Puget Lowland. A constant $\mathrm{Vp} / \mathrm{Vs}$ conversion factor of 2 was imposed on the Tertiary subunit to obtain Vs. Rho was derived from Vp using the empirical relationship of Brocher (2005).

\section{Continental Crust}

Topography is not included in this current model. The surface of the continental crust below Mean Sea Level was controlled by the smoothed continental shoreline as well as numerous published active and passive source results along the continental margin (for example, Trehu and others, 1994; Clowes and others, 1997; Flueh and others, 1998; Fuis, 1998; Gulick and others 1998; Fleming and Trehu, 1999; Parsons and others, 1999; Stanley and Villasenor, 2000; Bostock and others, 2002; and Ramachandran and others, 2004). This unit's Vp is derived from the above-mentioned studies and, most prominently, from the 3D tomography model of Ramachandran and others $(2004,2006)$ through the Puget Lowland. Properties Vs and rho were derived from Vp using the empirical relationship of Brocher (2005).

\section{Continental Mantle}

The top of continental mantle is derived from data of Chulick and Mooney (2002). These data were edited and smoothed to create the surface of this unit. The tomography of Stanley and others (1999) from the Puget Lowland area was used to

constrain upper mantle Vp, extrapolating a generalized Vp-depth structure throughout the 
unit. Rho and Vs were derived from Vp using the empirical relationship of Brocher (2005).

\section{Oceanic Sediments}

The oceanic sediment unit represents accreted and sedimentary deposits overlying the top of the continental crustal unit and underlying the eastern portion of the bathymetric surface. Parameter Vp is derived from results of Parsons and others (1999) and numerous active-source marine seismic surveys (for example,). Parameter Vp varies primarily as a function of depth. Parameters Vs and rho were derived from Vp using the empirical relationship of Brocher (2005). Preliminary ground motion studies suggest this unit will be subject to more intense shaking during a Cascadia megathrust event than other units of similar distance from the fault rupture (Olsen and other, in press).

\section{Oceanic Crust}

The top of the oceanic crustal unit is defined in the subsurface based on the results of Flück and others (1997) and McCrory and others (2005). These data are merged with bathymetric data west of the oceanic sediment terminus to create the oceanic crust surface. The top of oceanic crust in the subsurface is also defined to be the top of the Cascadia megathrust (subducting slab). Based on available marine seismic-reflection profiling (for example, Fuis, 1998) and studies worldwide (for example, Turcotte and Shubert, 1982), the thickness of the oceanic crust was set to $5 \mathrm{~km}$. This thickness is most likely on the low end of realistic values. Average values derived from marine seismic surveys were extrapolated to obtain Vp (for example, Trehu and others, 1994; Flueh and others, 1998; Fuis, 1998; Gulick and others 1998; Fleming and Trehu, 1999; and Ramachandran and others, 2004, 2006) and extrapolated smoothly to $60 \mathrm{~km}$ depth. Rho 
and Vs were derived from Vp using the empirical relationship of Brocher (2005). As the oceanic crust subducts into the mantle, the crust at depth is less dense and slower than the surrounding mantle to the bottom of the model at $60 \mathrm{~km}$ depth.

\section{Oceanic Mantle}

The ocean mantle is the only unit in the model underlying oceanic crust. The top surface is derived by down-projecting the top of the oceanic crust $5 \mathrm{~km}$ and smoothing the resulting surface. This unit has the poorest-resolved Vp, Vs, and rho parameters because of limited published results. Parameter Vp was set to vary from 7,900 m/s to $8,300 \mathrm{~m} / \mathrm{s}$ between about $10 \mathrm{~km}$ and $60 \mathrm{~km}$ depth, respectively. Parameters Vs and rho were derived from Vp using the empirical relationship of Brocher (2005).

\section{Discussion and Summary}

The first two sets of incremental property slices discussed here are from the Vs model volume because of this property's importance for earthquake ground motion characterization. In figure 4, east-west slices spaced every $200 \mathrm{~km}$ through the model reveal the subducting slab and areas of the model with higher apparent resolution in western Washington due in large part to P-wave tomography results using SHIPS data (for example, Brocher and others, 2001; Ramachandran and others, 2004, 2006).

Elevation slices from the Vs property volume from -4 to $-44 \mathrm{~km}$, every $10 \mathrm{~km}$, are shown in figure 5. Velocities for Vs range from $600 \mathrm{~m} / \mathrm{s}$ to $4,830 \mathrm{~m} / \mathrm{s}$. The $-4 \mathrm{~km}$ elevation slice shows the oceanic sediment as the arc-shaped light-blue-colored band of approximately $2,000 \mathrm{~m} / \mathrm{s}$. Small light-blue patches in the northeast quadrant of this slice are lowvelocity sediments within basins of the Puget Lowland. Subducting oceanic crust is 
clearly visible in the depth slices $-14 \mathrm{~km}$ to $-44 \mathrm{~km}$. At elevations below $-14 \mathrm{~km}$, oceanic mantle Vs is consistently higher than continental units at the same elevation.

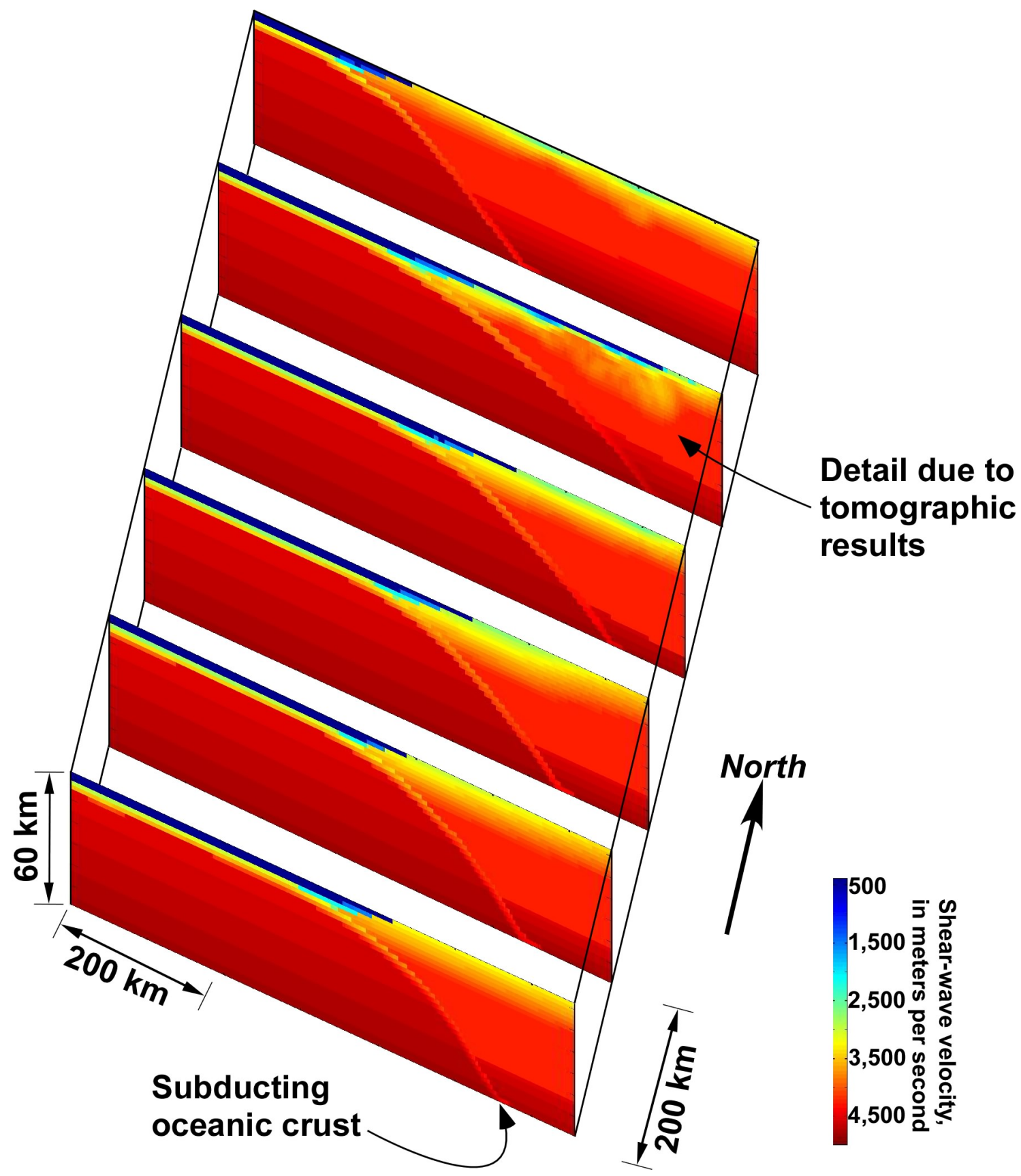

Figure 4. East-west slices through Vs model every $200 \mathrm{~km}$. Velocities are scaled from 400 to $5,000 \mathrm{~m} / \mathrm{s}$. Water velocity is set to $0 \mathrm{~m} / \mathrm{s}$. 


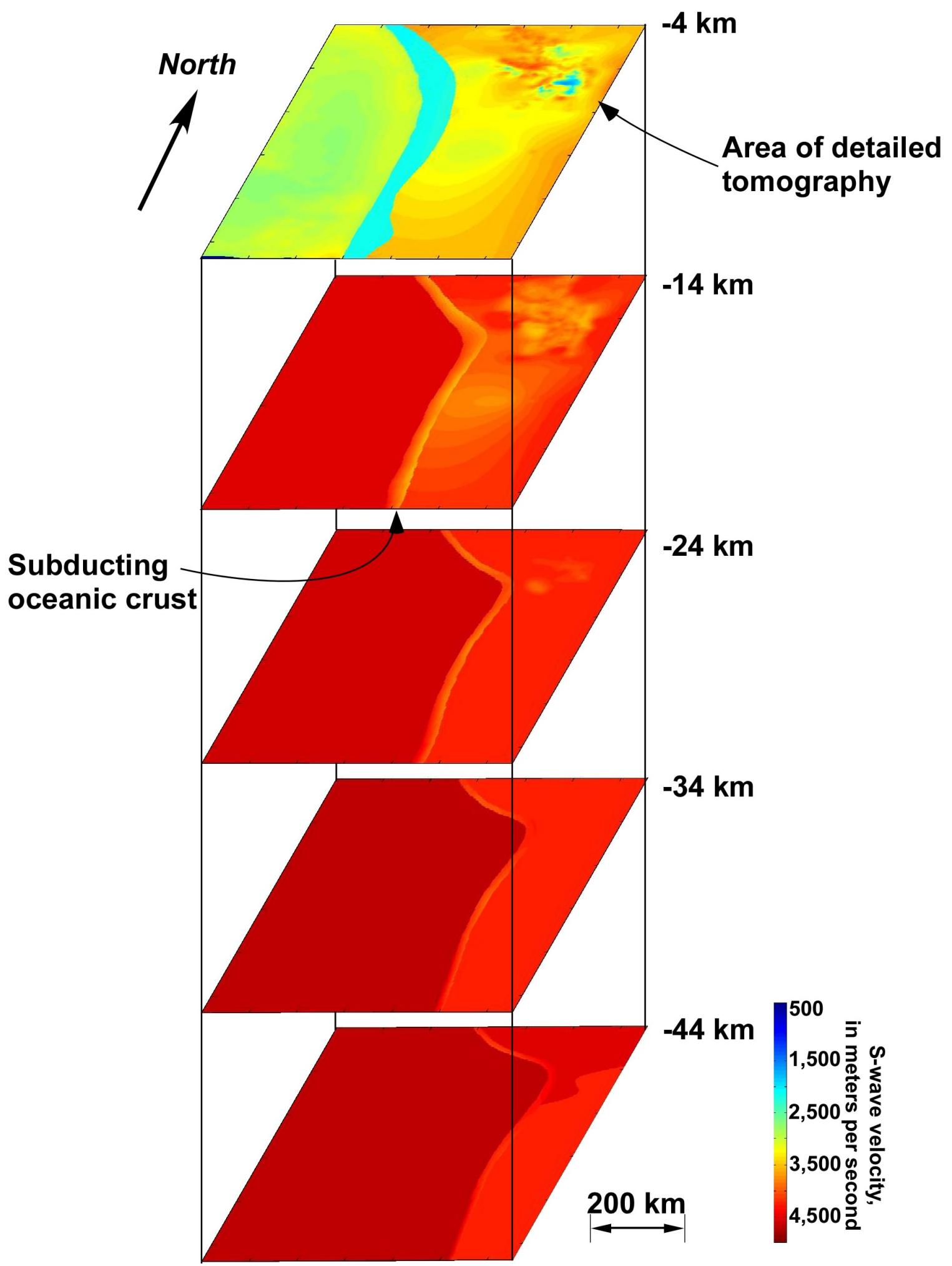

Figure 5. Vs model slices at $10-\mathrm{km}$ elevation intervals, beginning at $-4 \mathrm{~km}$ elevation. Velocity scale is same as in figure 4. 
Property Vp slices, corresponding in elevation to the Vs slices in figure 5, are shown in figure 6 . Velocities range from $1,290 \mathrm{~m} / \mathrm{s}$ to $8,470 \mathrm{~m} / \mathrm{s}$ in the $\mathrm{Vp}$ model. The $\mathrm{Vp} / \mathrm{Vs}$ elevation slices, shown in figure 7, reveal that nominal ratios in the deeper crust and mantle range between 1.71 and 1.76 . The mean $\mathrm{Vp} / \mathrm{Vs}$ between $-15 \mathrm{~km}$ and $-60 \mathrm{~km}$ elevation is approximately 1.733 , consistent with a Poisson solid value of $1.732 \mathrm{~g} / \mathrm{cm}^{3}$ for non-ocean-water regions. Property $\mathrm{Vp} / \mathrm{Vs}$ varies most markedly at elevations above -2 $\mathrm{km}$, where the ratio goes as high as 2.5 in urban sedimentary basins in the upper few hundred meters. Property rho elevation slices, again corresponding to those displayed for Vs in figure 5, are shown in figure 8 . These values for rock units range from $2.0 \mathrm{~g} / \mathrm{cm}^{3}$ in Quaternary basin sediments up to $3.46 \mathrm{~g} / \mathrm{cm}^{3}$ for ocean mantle at great depth.

The model volume in the immediate vicinity of Seattle, including most of the Puget Lowland, has been validated with ground motion simulations of the 2001 Nisqually earthquake as well as other weak-motion events (Frankel and others, 2006, 2007). The Vs, Vp, and rho model volumes were implemented in these ground motion simulations, and these results were incorporated into the U.S. Geological Survey Urban Hazards Maps for Seattle. The Seattle urban hazard model volume was a subset of the greater Cascadia velocity-density model volume. These finite difference simulations with these velocitydensity models have been qualitatively accurate at matching waveform data to $1 \mathrm{~Hz}$. 


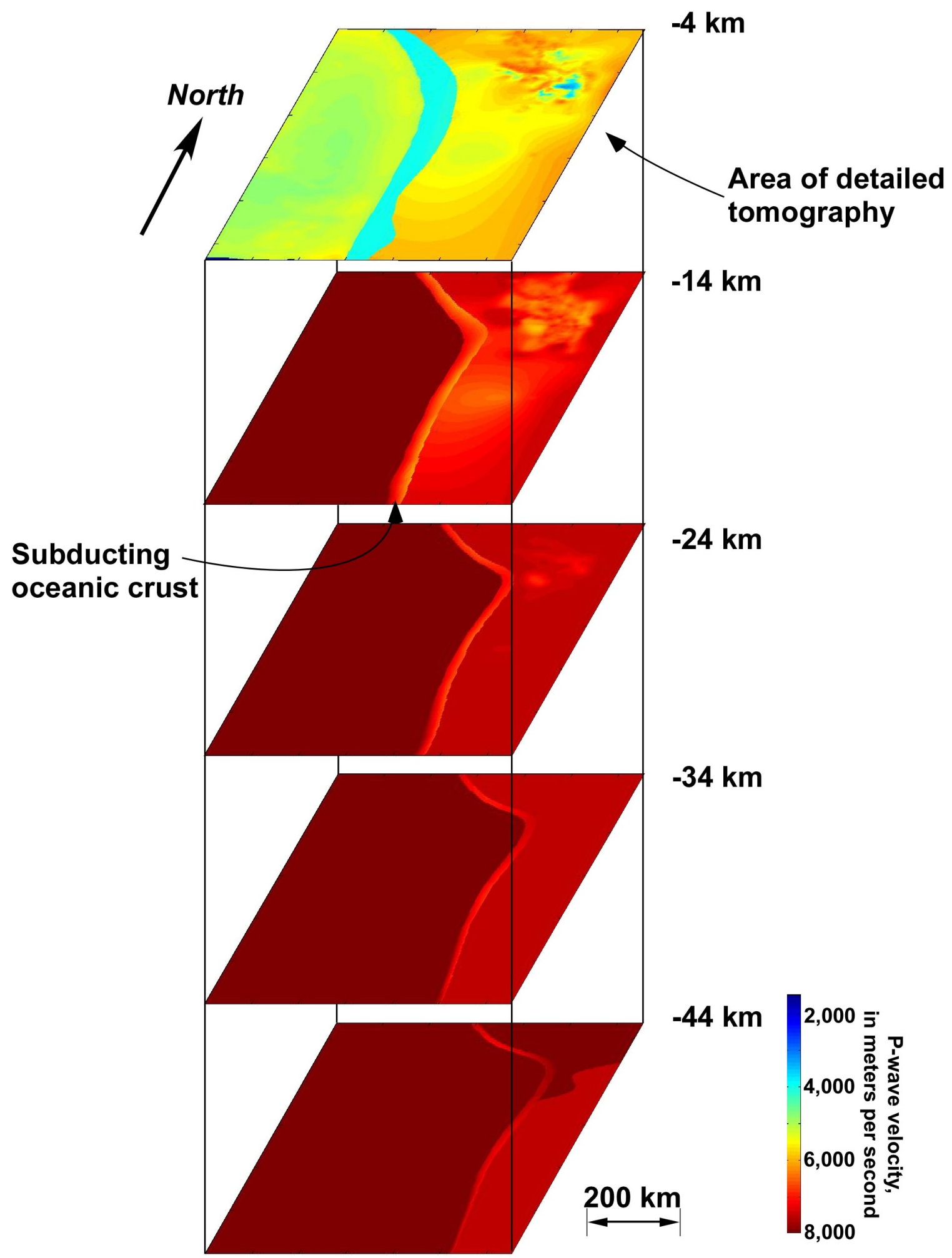

Figure 6. Vp model slices at $10-\mathrm{km}$ elevation intervals, beginning at $-4 \mathrm{~km}$ elevation (same elevations as slices shown in figure 5). 


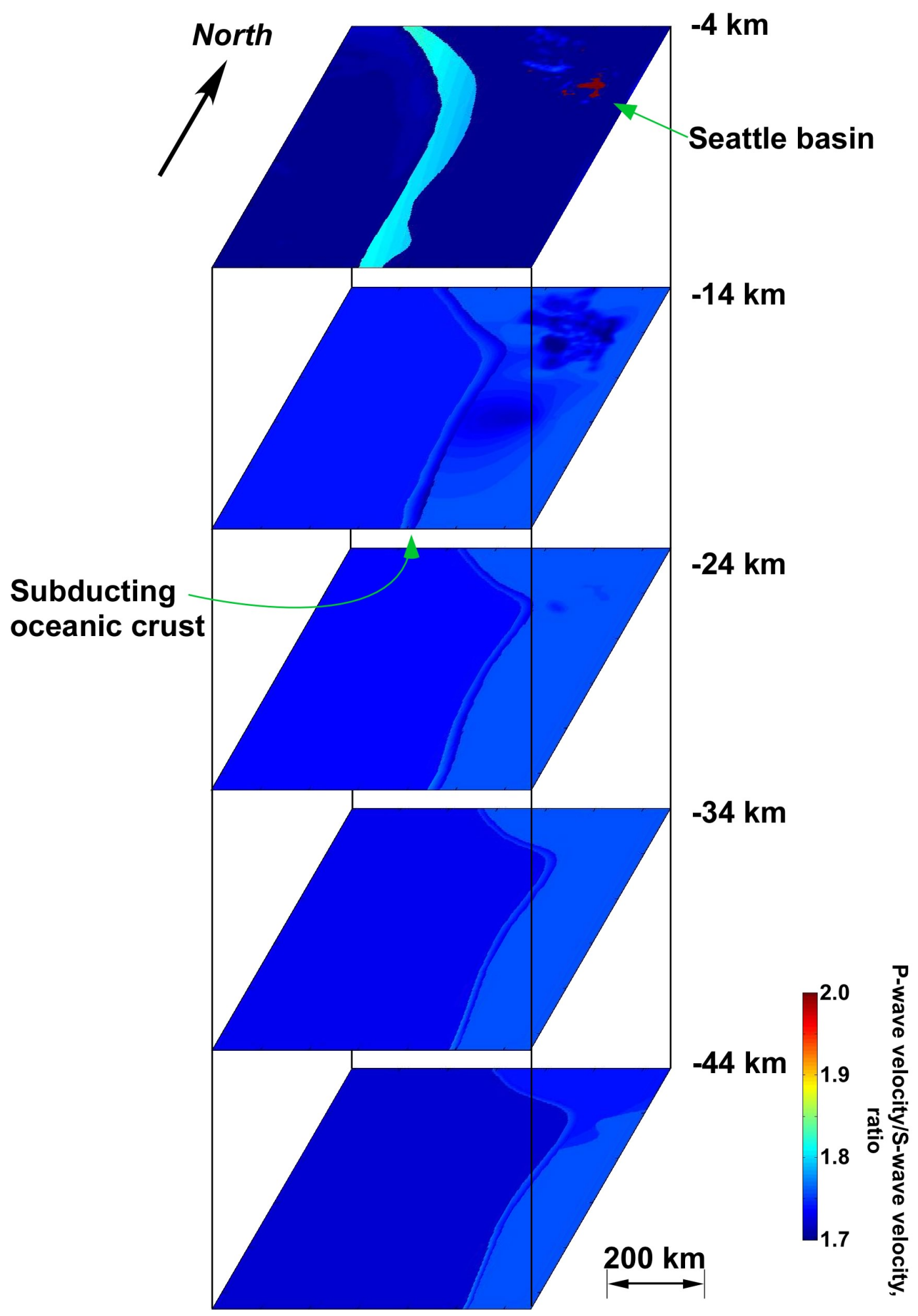

Figure 7. $\mathrm{Vp} / \mathrm{Vs}$ model slices at $10-\mathrm{km}$ elevation intervals, beginning at $-4 \mathrm{~km}$ elevation (same elevations as slices shown in figure 5). 


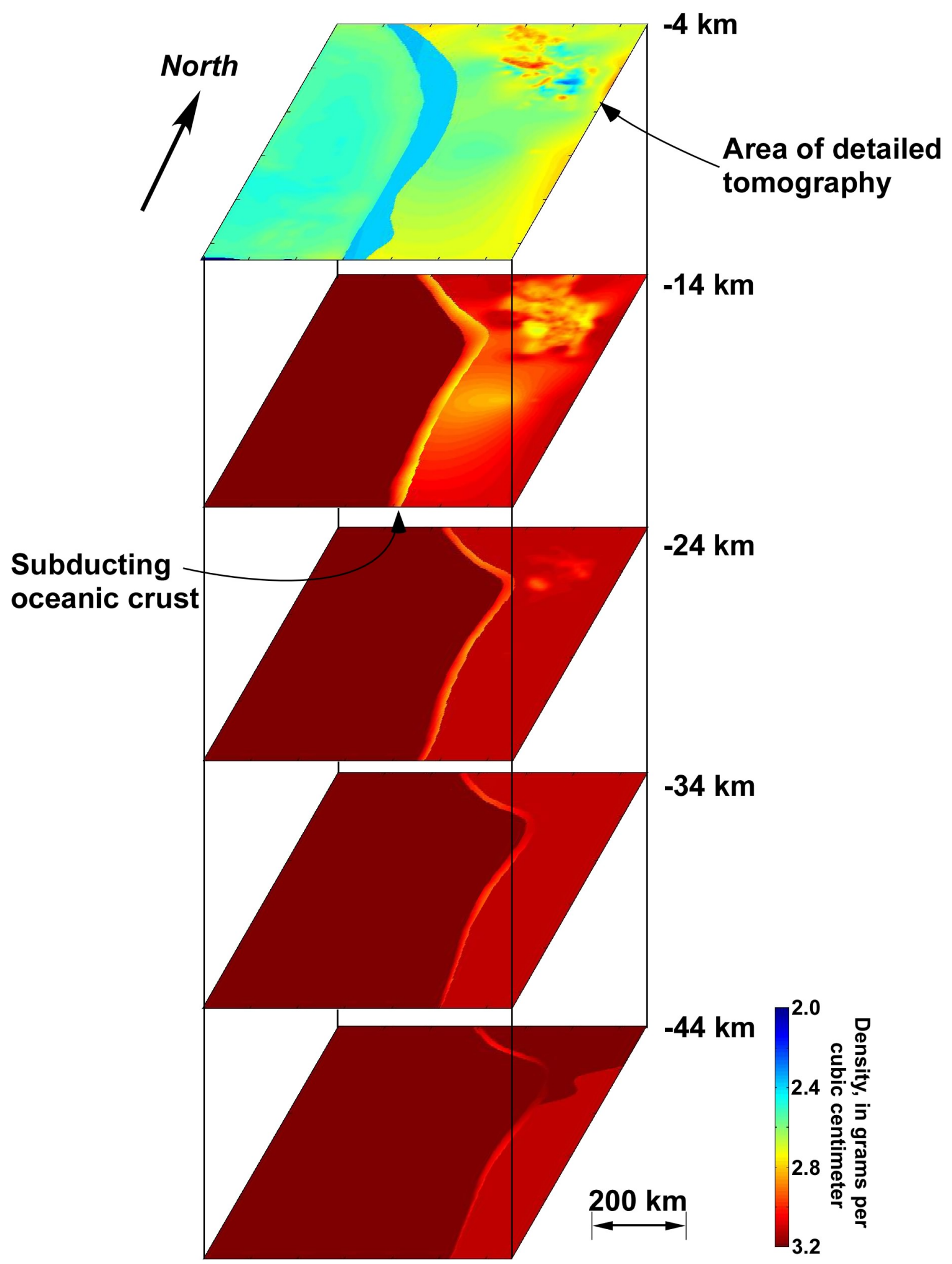

Figure 8. Rho model slices at $10-\mathrm{km}$ elevation intervals, beginning at $-4 \mathrm{~km}$ elevation (same elevations as slices in figure 5). 
The 3D velocity and density property models described in this paper were developed in FY2005 and FY2006 for use in strong ground motion simulations of Seattle fault, Cascadia megathrust, and other earthquake events of interest. These models were derived primarily using published geophysical data in addition to borehole and other geological constraints. The model volume as developed in EarthVision ${ }^{\circledR}$ is designed to be flexible and can be modified to add further complexity as new published information becomes available or as scientific focus is redirected to new challenges in the Cascadia region. This flexibility allows model grid, or node, spacing to be customized from the EarthVision $^{\circledR}$ model for a user's specific purpose. At present, the model can be obtained from the author (wstephens@usgs.gov) in raw IEEE binary format.

\section{Acknowledgments}

I thank Art Frankel for his patience and advice through the various permutations of this model volume's development. I also thank Jack Odum and Robert Williams for their reviews, which greatly improved this manuscript. Discussions with Kim Olsen, Todd Wagner, and Paul Vincent helped prompt me to formally complete this documentation.

\section{References Cited}

Blakely, R.J., Wells, R.E., Weaver, C.S., and Johnson, S.Y., 2002, Location, structure, and seismicity of the Seattle fault zone, Washington-Evidence from aeromagnetic anomalies, geologic mapping, and seismic-reflection data: Geological Society of America Bulletin, v. 114, p. 169-177. 
Bostock, M.G., Hyndman, R.D., Rondenay, S., and Peacock, S.M., 2002, An inverted continental Moho and serpentinization of the forearc mantle: Nature, v. 417, p. $536-538$.

Brocher, T.M., 2005, Empirical relations between elastic wavespeeds and density in the Earth's crust: Bulletin of the Seismological Society of America, v. 95, no. 6, p. $2,081-2,092$.

Brocher, T.M., Parsons, T., Blakely, R.J., Christensen, N.I., Fisher, M.A., Wells, R.E., SHIPS Working Group, 2001, Upper crustal structure in Puget Lowland, Washington—Results from the 1998 Seismic Hazards Investigation in Puget Sound: Journal of Geophysical Research, v. 106, no. B7, p. 13,541-13,564.

Brocher, T., and Ruebel, A.L., 1998, Compilation of 29 sonic and density logs from 23 oil test wells in western Washington state: U.S. Geological Survey, Open File Report 98-249.

Calvert, A.J., Fisher, M.A., Johnson, S.Y., Brocher, T.M., Creager, K.C., Crosson, R.S., Hyndman, R.D., Miller, K.C., Mosher, D., Parsons, T., Pratt, T.L., Spence, G., ten Brink, U., Trehu, A.M., and Weaver, C.S., 2003, Along-strike variations in the shallow seismic velocity structure of the Seattle fault zone-Evidence for fault segmentation beneath Puget Sound: Journal of Geophysical Research, v. 108, p. ESE1-14.

Chulick, G.S., and Mooney, W.D., 2002, Seismic structure of the crust and uppermost mantle of North America and adjacent oceanic basins-A synthesis: Bulletin of the Seismological Society of America, v. 92, no. 6, p. 2,478-2,492. 
Clowes, R.M., Baird, D.J., and Dehler, S.A., 1997, Crustal structure of the Cascadia subduction zone, southwestern British Columbia, from potential field and seismic studies: Canadian Journal of Earth Science, v. 34, p. 317-335.

Fleming, S.W., and Trehu, A.M., 1999, Crustal structure beneath the central Oregon convergent margin from potential-field modeling-Evidence for a buried basement ridge in local contact with a seaward dipping backstop: Journal of Geophysical Research, v. 104, no. B9, p. 20,431-20,447.

Flück, P., Hyndman, R.D., and Wang, K., 1997, Three-dimensional dislocation model for great earthquakes of the Cascadia subduction zone: Journal of Geophysical Research, v. 102, no. B9, p. 20,539-20,550.

Flueh, E.R., Fisher, M.A., Bials, J., Childs, J.R., Klaeschen, D., Kukowski, N., Parsons, T., Scholl, D.W., ten Brink, U., Trehu, A.M., and Vidal, N., 1998, New seismic images of the Cascadia subduction zone from cruise SO108-ORWELL: Tectonophysics, v. 293, p. 69-84.

Frankel, A.D., and Stephenson, W.J., 2000, Modeling observed ground motions in Seattle using three-dimensional simulations: Bulletin of the Seismological Society of America, v. 90, no. 5, p. 1,251-1,267.

Frankel, A.D., Stephenson, W.J., Carver, D.L., Williams, R.A., Odum, J.K., and Rhea, S.B., 2006, Seismic hazard maps for Seattle that include 3D sedimentary basin effects, rupture directivity, and site response, in U.S. National Conference on Earthquake Engineering, 8, Proceedings: Earthquake Engineering Research Institute, paper no. 1799 , p. 1-11.

Frankel, A.D., Stephenson, W.J., Carver, D.L., Williams, R.A., Odum, J.K., and Rhea, S.B., 2007, Seismic hazard maps for Seattle, Washington incorporating 3D 
sedimentary basin effects, nonlinear site response, and rupture directivity: U.S.

Geological Survey, Open-File Report 2007-1175.

Fuis, G.S., 1998, West margin of North America—A synthesis of recent seismic transects: Tectonophysics, v. 288, p. 265-292.

Gannett, M.W, and Caldwell, R.R, 1998, Geologic framework of the Willamette Lowland Aquifer System, Oregon and Washington: U.S. Geological Survey, Professional Paper 1424-A, 32 p., 8 plates.

Gulick, S.P.S., Meltzer, A.M., Clarke, S.H., 1998, Seismic structure of the southern Cascadia subduction zone and accretionary prism north of the Mendocino triple junction: Journal of Geophysical Research, v. 103, no. B11, p. 27,207-27,222.

Johnson, S.Y., Dadisman, S.V., Childs, J.R., and Stanley, W.D., 1999, Active tectonics of the Seattle fault and central Puget Sound, Washington-Implications for earthquake hazards: Geological Society of America Bulletin, v. 111, p. 1,042-1,053.

Jones, M.A., 1996, Thickness of unconsolidated deposits in the Puget Sound Lowland, Washington and British Columbia: U.S. Geological Survey, Water-Resources Investigations Report, WRI 94-4133, 1 sheet.

McCrory, P.A., Blair, J.L., Oppenheimer, D.H., and Walter, S.R., 2005, Depth to the Juan de Fuca Slab beneath the Cascadia subduction margin-A 3-D model for sorting earthquakes: U.S. Geological Survey, Data Series 91.

McPhee, D.K., Langenheim, V.E., Blakely, R.J., Morin, R., and Wells, R.E., 2007, Geophysical modeling across the Tualatin basin, Oregon, and implications on seismic hazards and water resources: Geological Society of America Cordilleran Section, $103^{\text {rd }}$ Annual Meeting, p. 17-8. 
Mosher, D.C., and Johnson, S.Y., 2000, Juan de Fuca Atlas-Neotectonics of the Eastern Juan de Fuca Strait. A digital geological and geophysical atlas: Geological Survey of Canada Open File No. 3931.

Olsen, K.B., Stephenson, W.J., and Geisselmeyer, A., in press, 3D crustal structure and long-period ground motions from a M9.0 megathrust earthquake in the Pacific Northwest Region: Journal of Seismology, 17 p.

Parsons, T., Wells, R.E., Fisher, M.A., Flueh, E., and ten Brink, U.S., 1999, Threedimensional velocity structure of Siletzia and other accreted terranes in the Cascadia forearc of Washington: Journal of Geophysical Research, v. 104, no. B8, p. $18,015-18,039$.

Pitarka, A., Graves, R., and Somerville, P., 2004, Validation of a 3D velocity model of the Puget Sound region based on modeling ground motion from the 28 February 2001 Nisqually Earthquake: Bulletin of the Seismological Society of America, v. 94 , no. 5 , p. $1,670-1,689$.

Pratt, T.L, Johnson, S.Y., Potter, C.J., Stephenson, W.J., and Finn, C., 1997, Seismic reflection images beneath Puget Sound, western Washington State-The Puget Lowland thrust sheet hypothesis: Journal of Geophysical Research, v. 102, no. B12, p. 27,469-27,489.

Ramachandran, K., Hyndman, R.D., and Brocher, T.M., 2004, Structure of the northern Cascadia subduction zone-A 3-D tomographic P-wave velocity model: EOS, v. 85, no. 47, fall meeting supplement, S51B-016.

Ramachandran, K., Hyndman, R.D., and Brocher, T.M., 2006, Regional P wave velocity structure of the northern Cascadia subduction zone: Journal of Geophysical Research, v. 111, no. B12, p. B12,301. 
Stanley, D., and Villasenor, A., 2000, Models of downdip frictional coupling for the Cascadia megathrust: Geophysical Research Letters, v. 27, no. 10, p. 1,551-1,554. Stanley, D., Villasenor, A., and Benz, H., 1999, Subduction zone and crustal dynamics of western Washington—A tectonic model for earthquake hazards evaluation: U.S. Geological Survey, Open File Report 99-311, http://pubs.usgs.gov/of/1999/ofr990311.

Stephenson, W.J., and Frankel, A.D., 2003, Development of a 3D velocity and density model for the Cascadia subduction zone and preliminary finite-difference modeling results: Geological Society of America Abstracts with Programs, v. 35, no. 6, p. 263. ten Brink, U.S., Molzer, P.C., Fisher, M.A., Blakely, R.J., Bucknam, R.C., Parsons, T., Crosson, R.S., and Creager, K.C., 2002, Subsurface geometry and evolution of the Seattle Fault Zone and the Seattle Basin, Washington: Bulletin of the Seismological Society of America, v. 92, no. 5, p. 1,737-1,753.

Trehu, A.M., Asudeh, I., Brocher, T.M., Luetgert, J.H., Mooney, W.D., Nabelek, J.L., and Nakamura, Y., 1994, Crustal architecture of the Cascadia forearc: Science, v. 266, p. 237-242.

Turcotte, D.L., and Schubert, G., 1982, Geodynamics-Applications of continuum physics to geological problems: New York, John Wiley \& Sons, p. 12.

Van Wagoner, T.M., Crosson, R.S., Creager, K.C., Medema, G., Preston, L., Symons, N.P., and Brocher, T.M., 2002, Crustal structure and relocated earthquakes in the Puget Lowland, Washington, from high-resolution seismic tomography: Journal of Geophysical Research, v. 107, p. 2,381-2403.

Wessel, P., and Smith, W.H.F., 1991, Free software helps map and display data: EOS, v. 72, no. 41, fall meeting supplement, p. 441. 
Williams, R.A., Stephenson, W.J., Frankel, A.D., and Odum, J.K., 1999, Surface seismic measurements of near-surface $\mathrm{P}$ - and $\mathrm{S}$-wave seismic velocities at earthquake recording stations, Seattle, Washington: Earthquake Spectra, v. 15, no. 3, p. 565584.

Yeats, R.S., Graven, E.P., Werner, K.S., Goldfinger, C., and Popowski, T.A., 1996, Tectonics of the Willamette Valley, Oregon, in Rogers, A.M., Walsh, T.J., Kockelman, W.J., and Priest, G.R., eds., Assessing earthquake hazards and reducing risk in the Pacific Northwest (v. 1): U.S. Geological Survey Professional Paper 1560, p. 183-222. 